\title{
COVID-19 and Effect on Liver Transplant
}

\author{
Yael R. Nobel, MD \\ Meaghan Phipps, MD \\ Elizabeth C. Verna, MD, MS
}

\section{Address}

*Division of Digestive and Liver Diseases, Columbia University Irving Medical Center, New York, NY, USA

Email: ev77@cumc.columbia.edu

Published online: 16 August 2021

(C) The Author(s), under exclusive licence to Springer Science+Business Media, LLC, part of Springer Nature 2021

This article is part of the Topical Collection on Liver

Keywords SARS-CoV-2 · COVID-19 • Liver transplantation · Solid organ transplant · Chronic liver disease

\begin{abstract}
Purpose of review The Coronavirus disease-2019 (COVID-19) pandemic has significantly impacted all aspects of liver transplantation. We reviewed the literature regarding COVID19 clinical outcomes, treatment, and vaccination of liver transplant candidates and recipients.

Recent findings Patients with chronic liver disease, especially with cirrhosis, have higher morbidity and mortality from COVID-19 than patients without liver disease. Increased mortality has not been consistently seen in liver transplant recipients, in whom severe disease is more strongly associated advanced age and medical comorbidities, rather than with transplant-specific factors. While several targeted COVID-19 therapies have reported hepatotoxicity, these therapies may be safe and effective in patients with liver disease and liver transplant recipients. Questions remain regarding whether SARS-CoV-2 can be transmitted via the donor liver and whether transplant is safe in patients and/or donors with recent or active COVID-19.

Summary COVID-19 has significantly affected the care of liver transplant candidates and recipients. Guidelines for the safe practice of liver transplantation are rapidly evolving, and current recommendations are discussed.
\end{abstract}

\section{Introduction}

Coronavirus disease-2019 (COVID-19), the disease caused by severe acute respiratory syndrome coronavirus-2 (SARS-CoV-2), has had an enormous impact on healthcare systems worldwide, not only via morbidity and mortality but also through major disruption of healthcare practices and procedures. As of April 
2021, there have been over 500,000 COVID-related deaths in the U.S. and over 2.9 million deaths worldwide [1]. Patients with chronic diseases and immunosuppression, including those with chronic liver disease and recipients of liver transplant, may have increased risk for severe disease $[2 \bullet, 3,4 \bullet 5]$. A number of treatment options are available for use in patients with liver disease, although concerns about hepatotoxicity with many of these agents may limit use in some cases [6]. More recently, vaccination against COVID-19 has offered an important preventive strategy for patients with liver disease $[7,8 \bullet]$.
In addition to individual patient considerations, policies and practice of liver transplantation have been deeply impacted by the pandemic. After initial declines, numbers of liver transplants performed in the U.S. rebounded in the second half of 2020, with new policies and society recommendations in place guiding SARS-CoV-2 testing in transplant recipients and donors $[9 \bullet, 10 \bullet]$. However, multiple questions remain regarding timing and safety of liver transplant in recipients or donors with positive SARSCoV-2 test.

\section{Clinical outcomes of COVID-19 in patients with chronic liver disease and cirrhosis}

A number of studies have evaluated clinical outcomes of COVID-19 in patients with preexisting advanced liver disease, including patients with and without cirrhosis (summarized in Table 1). Compared to patients without preexisting liver disease, patients with chronic liver disease or cirrhosis have a higher rate of mortality and other severe clinical outcomes (admission to an intensive care unit [ICU] and need for mechanical ventilation), though specific rates have varied. Patients with chronic liver disease-especially nonalcoholic fatty liver disease (NAFLD)-are overrepresented among those hospitalized for COVID-

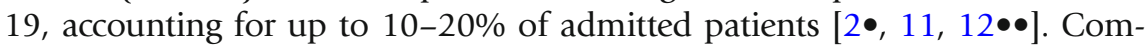
pared to patients without chronic liver disease, those with chronic liver disease have higher rates of ICU admission, need for mechanical ventilation, and mortality [11]. Specific predictors of mortality include alcohol-related liver disease, especially among patients with noncirrhotic chronic liver disease; presence of hepatic decompensation; and presence of medical comorbidities such as hypertension, diabetes, or cardiovascular disease $[2 \bullet, 12 \bullet \bullet, 13 \bullet \bullet]$.

Increasing severity of preexisting liver disease-including cirrhosis compared to noncirrhosis, or increasing Child-Pugh Class indicating more decompensated underlying disease - has been consistently associated with higher rates of mortality $[2 \bullet, 12 \bullet \bullet, 13 \bullet \bullet, 14]$. When looking specifically at patients with cirrhosis and COVID-19, several multicenter studies in the U.S., Europe, and China have found a mortality rate over $20-30 \%$, significantly higher than among patients with COVID-19 without cirrhosis $[2 \bullet, 11,12 \bullet \bullet, 15-17]$. In a study based on two international registries that included 745 patients with chronic liver disease and COVID-19 infection, for example, there was 32\% mortality in patients with cirrhosis compared to $8 \%$ in those without cirrhosis $(p<0.001)[13 \bullet \bullet]$. Among patients with cirrhosis, in whom morbidity and mortality is often tied to infection, COVID-19 may produce more severe clinical outcomes than other infections. In a retrospective multicenter study in Italy, for example, patients with cirrhosis with COVID-19 had 34\% 30-day mortality rate, significantly higher than among patients with cirrhosis hospitalized for bacterial infections [11]. However, in a multicenter U.S. study, there was a trend toward higher mortality among patients with cirrhosis and COVID-19 
Table 1. Outcomes of COVID-19 among patients with cirrhosis and liver transplant recipients

\begin{tabular}{|c|c|c|c|}
\hline $\begin{array}{l}\text { Study } \\
\text { (date, } \\
\text { region, } \\
\text { number of } \\
\text { sites) }\end{array}$ & $\begin{array}{l}\text { Patient cohort and } \\
\text { comparator(s) }\end{array}$ & Main outcomes & Other findings \\
\hline $\begin{array}{l}\text { Qi et al. } \\
\text { - May } 2020 \\
\text { - China } \\
\text { - } 16 \text { centers }\end{array}$ & $\begin{array}{l}\text { - Primary cohort: } 21 \text { patients with } \\
\text { cirrhosis } \\
\text { - No comparator group }\end{array}$ & $\begin{array}{l}23.8 \% \text { mortality rate among } \\
\text { primary cohort }\end{array}$ & $\begin{array}{l}\text { - Laboratory findings associated } \\
\text { with higher mortality: lower } \\
\text { total lymphocyte count, lower } \\
\text { platelet count, and higher } \\
\text { direct bilirubin }\end{array}$ \\
\hline $\begin{array}{l}\text { Singh and } \\
\text { Khan } \\
\text { - May } 2020 \\
\text { - United } \\
\text { States } \\
\text { - } 34 \text { centers }\end{array}$ & $\begin{array}{l}\text { - Primary cohort: } 250 \text { patients } \\
\text { with CLD, including } 50 \text { patients } \\
\text { with cirrhosis } \\
\text { - Comparator group: liver disease } \\
\text { vs. no liver disease using } \\
\text { propensity score matching for BMI, } \\
\text { HTN, DM, age, race, and nicotine } \\
\text { use }\end{array}$ & $\begin{array}{l}\text { - Higher risk of mortality in liver } \\
\text { disease vs. no liver disease (RR } \\
2.8,95 \% \text { CI 1.9-4.0) } \\
\text { - Highest risk of mortality in } \\
\text { cirrhosis vs. no liver disease (RR 4.6, } \\
95 \% \text { CI 2.6-8.3) }\end{array}$ & $\begin{array}{l}\text { - ALT elevations ( }>50 \mathrm{U} / \mathrm{L} \text { ) seen in } \\
46.1 \% \text { of patients with liver } \\
\text { disease and } 50.6 \% \text { of patients } \\
\text { without liver disease }\end{array}$ \\
\hline $\begin{array}{l}\text { Iavarone } \\
\text { et al. } \\
\text { - June } 2020 \\
\text { - Italy } \\
\text { - } 9 \text { centers }\end{array}$ & $\begin{array}{l}\text { - Primary cohort: } 50 \text { patients with } \\
\text { cirrhosis } \\
\text { - Comparator group: patients } \\
\text { hospitalized for hepatic } \\
\text { decompensation due to bacterial } \\
\text { infection over preceding year }\end{array}$ & $\begin{array}{l}\text { - } 30 \text {-day mortality rate of } 34 \% \\
\text { among primary cohort, } \\
\text { significantly higher than in } \\
\text { comparator group }\end{array}$ & $\begin{array}{l}\text { - Respiratory failure and } \\
\text { worsening liver function during } \\
\text { SARS-CoV-2 infection } \\
\text { associated with higher } \\
\text { mortality }\end{array}$ \\
\hline $\begin{array}{l}\text { Bajaj et al. } \\
\text { - July } 2020 \\
\text { - United } \\
\text { States } \\
\text { - } 7 \text { centers }\end{array}$ & $\begin{array}{l}\text { - Primary cohort: } 37 \text { patients with } \\
\text { cirrhosis } \\
\text { - Comparator groups (age and } \\
\text { gender-matched): (1) } 108 \text { patients } \\
\text { with COVID-19 without cirrhosis } \\
\text { and (2) } 127 \text { patients with cirrhosis } \\
\text { without COVID-19 }\end{array}$ & $\begin{array}{l}\text { Higher mortality in cirrhosis + } \\
\text { COVID-19 vs. COVID-19 alone } \\
\text { (30\% vs. } 13 \%) ; \text { similar } \\
\text { mortality in cirrhosis + } \\
\text { COVID-19 vs. cirrhosis alone } \\
(30 \% \text { vs. } 20 \%)\end{array}$ & $\begin{array}{l}\text { - Higher CCI was only predictor of } \\
\text { mortality across entire cohort }\end{array}$ \\
\hline $\begin{array}{l}\text { Hashemi } \\
\text { et al. } \\
\text { - July } 2020 \\
\text { - United } \\
\text { States } \\
\text { - } 9 \text { centers }\end{array}$ & $\begin{array}{l}\text { - Primary cohort: } 69 \text { patients with } \\
\text { CLD and } 9 \text { patients with } \\
\text { cirrhosis } \\
\text { - Comparator group: hospitalized } \\
\text { patients without CLD }\end{array}$ & $\begin{array}{l}\text { - Cirrhosis was associated with } \\
\text { higher mortality (aOR 12.5, } \\
\text { 95\% CI 2.16-72.5) }\end{array}$ & $\begin{array}{l}\text { - CLD and NAFLD were associated } \\
\text { with ICU admission, need for } \\
\text { mechanical ventilation, and } \\
\text { increased length of stay }\end{array}$ \\
\hline $\begin{array}{l}\text { Sarin et al. } \\
\text { - July } 2020 \\
\text { - Asia } \\
\text { - } 13 \text { countries }\end{array}$ & $\begin{array}{l}\text { - Primary cohort: } 228 \text { patients, } \\
\text { including } 185 \text { patients with CLD } \\
\text { and } 43 \text { patients with cirrhosis } \\
\text { - No comparator group }\end{array}$ & $\begin{array}{l}\text { - } 20 \% \text { of patients with cirrhosis } \\
\text { presented with ACLF or } \\
\text { decompensation from baseline } \\
\text { - Higher CTP class was associated } \\
\text { with increased risk of liver-related } \\
\text { complications }\end{array}$ & $\begin{array}{l}\text { - } 43 \% \text { of patients with CLD } \\
\text { presented with acute liver } \\
\text { injury } \\
\text { - Higher bilirubin and AST/ALT } \\
\text { ratio were associated with higher } \\
\text { mortality among patients with } \\
\text { cirrhosis }\end{array}$ \\
\hline $\begin{array}{l}\text { Kim and } \\
\text { Adeniji } \\
\text { et al. }\end{array}$ & $\begin{array}{l}\text { Primary cohort: } 867 \text { patients } \\
\text { with CLD, including } 227 \\
\text { patients with cirrhosis }\end{array}$ & $\begin{array}{l}\text { - } 14 \% \text { mortality rate among all } \\
\text { patients }\end{array}$ & $\begin{array}{l}\text { - Hispanic ethnicity and } \\
\text { decompensated cirrhosis }\end{array}$ \\
\hline
\end{tabular}


Table 1. (Continued)

\begin{tabular}{|c|c|c|c|}
\hline $\begin{array}{l}\text { Study } \\
\text { (date, } \\
\text { region, } \\
\text { number of } \\
\text { sites) }\end{array}$ & $\begin{array}{l}\text { Patient cohort and } \\
\text { comparator(s) }\end{array}$ & Main outcomes & Other findings \\
\hline $\begin{array}{l}\text { - September } \\
2020 \\
\text { - United } \\
\text { States } \\
\text { - } 21 \text { centers }\end{array}$ & & $\begin{array}{l}- \text { ALD, CTP class C, and HCC } \\
\text { associated with higher mortality }\end{array}$ & $\begin{array}{l}\text { associated with severe } \\
\text { COVID-19 }\end{array}$ \\
\hline $\begin{array}{l}\text { Marjot } \\
\quad \text { et al. } \\
\text { - October } \\
2020 \\
\text { - } \\
\text { International } \\
\text { registry } \\
\text { - } 29 \text { countries }\end{array}$ & $\begin{array}{l}\text { - Primary cohort: } 745 \text { patients } \\
\text { with CLD, including } 386 \\
\text { patients with cirrhosis } \\
\text { - Comparator group: } 620 \text { patients } \\
\text { without CLD using propensity score } \\
\text { matching }\end{array}$ & $\begin{array}{l}\text { - Higher mortality in cirrhosis vs. } \\
\text { CLD without cirrhosis ( } 32 \% \text { vs. } \\
8 \% \text { ) } \\
\text { - Mortality risk increased with } \\
\text { higher CTP class }\end{array}$ & $\begin{array}{l}\text { - Advanced age and ALD } \\
\text { associated with higher } \\
\text { mortality }\end{array}$ \\
\hline $\begin{array}{l}\text { Pereira } \\
\quad \text { et al. } \\
\text { - May } 2020 \\
\text { - New York } \\
\text { City, United } \\
\text { States } \\
\text { - } 2 \text { centers }\end{array}$ & $\begin{array}{l}\text { - Primary cohort: } 90 \text { SOT } \\
\text { recipients, including } 14 \text { liver } \\
\text { transplant recipients (13 liver } \\
\text { and } 1 \text { liver-kidney) } \\
\text { - No comparator group }\end{array}$ & $\begin{array}{l}\text { - Mortality rate of } 18 \% \text { among all } \\
\text { patients } \\
\text { - Moderate or severe COVID-19 in } \\
75 \% \text { of patients } \\
\text { - Outcomes did not differ by type of } \\
\text { organ transplant }\end{array}$ & $\begin{array}{l}\text { - Most common COVID-19 } \\
\text { directed treatment was HCQ } \\
\text { ( } 91 \% \text { of patients) }\end{array}$ \\
\hline $\begin{array}{l}\text { Bechetti } \\
\quad \text { et al. } \\
\text { - June } 2020 \\
\text { - Europe } \\
\text { - } 12 \text { centers }\end{array}$ & $\begin{array}{l}\text { - Primary cohort: } 57 \text { liver } \\
\text { transplant recipients } \\
\text { - No comparator group }\end{array}$ & $\begin{array}{l}\text { - } 12 \% \text { mortality rate, only } \\
\text { observed in hospitalized } \\
\text { patients }\end{array}$ & $\begin{array}{l}\text { - No difference in outcomes } \\
\text { among patients with IS } \\
\text { reduction }(37 \%) \text { or IS } \\
\text { discontinuation }(7 \%)\end{array}$ \\
\hline $\begin{array}{l}\text { Belli et al. } \\
\text { - June } 2020 \\
\text { - Europe } \\
\text { (mainly Italy, } \\
\text { Spain, France) } \\
\text { - } 56 \text { centers }\end{array}$ & $\begin{array}{l}\text { - Primary cohort: } 103 \text { liver } \\
\text { transplant recipients } \\
\text { - No comparator group }\end{array}$ & $\begin{array}{l}\text { - Mortality rate of } 16 \% \text {, only seen } \\
\text { in patients } 60 \text { years of age or } \\
\text { older }\end{array}$ & $\begin{array}{l}\text { - Higher mortality in patients at } \\
\text { least } 2 \text { years from date of } \\
\text { transplant vs. within } 2 \text { years } \\
\text { (18\% vs. } 5 \% \text {, not statistically } \\
\text { significant) }\end{array}$ \\
\hline $\begin{array}{l}\text { Colmenero } \\
\quad \text { et al. } \\
\text { - } \text { August } 2020 \\
\text { - Spain } \\
\text { - } 25 \text { centers }\end{array}$ & $\begin{array}{l}\text { - Primary cohort: } 111 \text { liver } \\
\text { transplant recipients } \\
\text { - Comparator group: matched } \\
\text { patients from general population } \\
\text { using SIR and SMR }\end{array}$ & $\begin{array}{l}\text { - Higher mortality in LT recipients } \\
\text { vs. general population ( } 18 \% \text { vs. } \\
14.9 \% \text {, SMR } 95.5 \text { ) } \\
\text { - No patient deaths reported in LT } \\
\text { recipients under the age of } 60\end{array}$ & $\begin{array}{l}\text { - Mycophenolate use associated } \\
\text { with risk of severe COVID-19 } \\
\text { (RR 3.94, 95\% CI 1.59-9.74), in } \\
\text { particular with doses higher } \\
\text { than } 1 \mathrm{~g} / \text { day } \\
\text { - CNIs and everolimus not } \\
\text { associated with increased risk of } \\
\text { severe COVID-19 }\end{array}$ \\
\hline $\begin{array}{l}\text { Webb et al. } \\
\text { - August } 2020 \\
\text { International } \\
\text { registry }\end{array}$ & $\begin{array}{l}\text { - Primary cohort: } 151 \text { liver } \\
\text { transplant recipients } \\
\text { - Comparator group: } 627 \text { non-LT } \\
\text { recipients with COVID-19 }\end{array}$ & $\begin{array}{l}\text { - Lower mortality in LT recipients } \\
\text { vs. non-LT recipients (19\% vs. } \\
27 \% \text { ) }\end{array}$ & $\begin{array}{l}\text { - Increased mortality associated } \\
\text { with older age, higher } \\
\text { creatinine, and nonliver cancer }\end{array}$ \\
\hline
\end{tabular}


Table 1. (Continued)

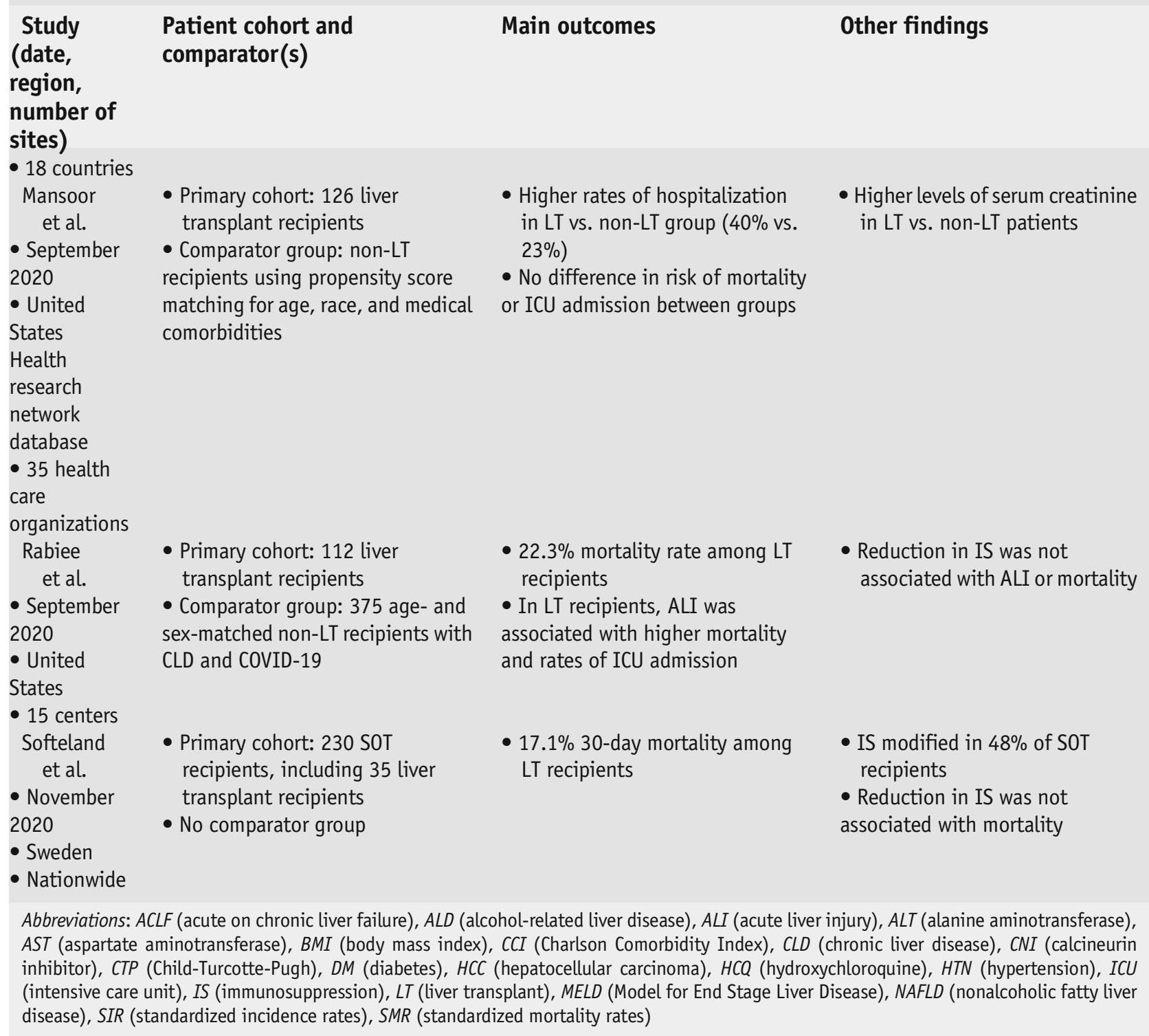

compared to age- and gender-matched patients with cirrhosis without COVID19 , but the difference was not statistically significant (30\% versus $20 \%$, respectively; $p=0.16$ ) - highlighting the impact of underlying cirrhosis itself upon inpatient mortality rates [15].

Mortality from COVID-19 among patients with chronic liver disease, as in patients without chronic liver disease, is driven largely by cardiopulmonary complications including respiratory failure, sepsis, and shock. However, liver injury and acute-on-chronic liver failure may also contribute to morbidity and mortality in these patients. Hepatic dysfunction and abnormal liver function 


\section{COVID-19 and the practice of liver transplantation}

\section{The impact of the COVID-19 pandemic on rates of liver transplantation}

As with all aspects of healthcare systems internationally, the practice of liver transplantation has been significantly impacted by the COVID-19 pandemic. Initial severe limitations in the ability to conduct liver transplant, especially in the early phases of the pandemic in 2020, are now giving way to resumption of practice with new policies and considerations in place.

In the early phases of the pandemic in the U.S. in winter-spring of 2020, there was an acute decline in the number of liver transplants performed across the country, as many centers either limited the number of transplants or temporarily ceased performing transplants altogether (Fig. 1). Compared to expected numbers based on prior years, in March-May 2020 there were markedly fewer patients added to the liver transplant waitlist and substantially more patients inactivated from the waitlist (Fig. 2); in states with the highest rates of COVID-19, for example, there was over 30\% reduction in new listings, over $30 \%$ reduction in deceased donor liver transplant, and nearly $60 \%$ increase in mortality of patients on the waitlist in the early phase of the pandemic [27]. There was significant variability in practice among specific transplant centers, even within the same geographic region, especially in regions with high rates of COVID-19.

Patterns in liver transplantation during the early months of the COVID19 pandemic reflected a combination of safety and logistical considerations. There were significant concerns about the risk to transplant recipients of SARS-CoV-2 acquisition at medical appointments or in the hospital, as well as either in the hospital or in the community after initiation of immunosuppressive medications posttransplant. Family and caregiver visitation continue to face restrictions both in hospitals and once patients are discharged home. SARS-CoV-2 testing abilities were limited, restricting the ability to test potential recipients or donors in a timely manner. In parallel, transplant teams-along with the entire medical community-faced severe shortages of personal protective equipment needed for surgery and other patient care, restricted operating room space and staffing, restricted postoperative intensive care unit or inpatient ward space and staffing, and state- or institutionguided limitations on group meetings. Some hepatologists and surgeons were "redeployed" to care for the influx of COVID-19 patients. Additional national considerations also impacted transplant practice-for example, the 


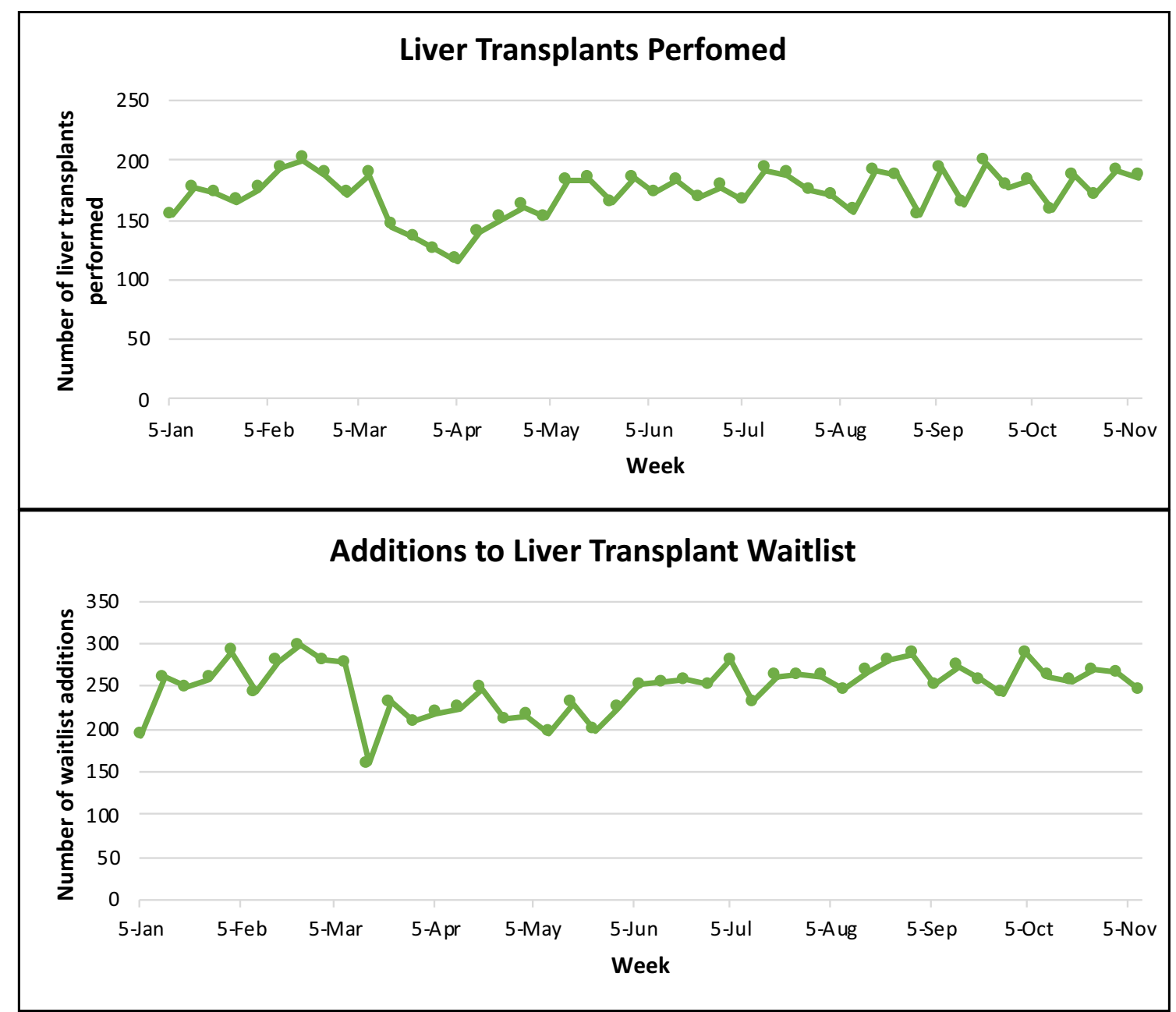

Fig. 1. Liver transplants performed and wait list additions in the US in 2020

major disruption in airline travel led to reduced ability to recover and transport organs to transplant centers [28].

Later in 2020, as centers mobilized to resume organ transplantation practice nearer to usual, rates of waitlist registration and deceased donor liver transplant increased to match or exceed expected levels, and the overall numbers of deceased donor liver transplants in 2020 actually exceeded those in 2019, reflecting increases in deceased organ donation in 38 of the 58 national organ procurement organizations $[27,29]$. Rates of living donor liver transplantation, on the other hand, faced more lasting reductions throughout the year than were seen with deceased donor liver transplantation. Although rates in the second half of the year began to approach expected prepandemic levels, by the end of the year in 2020 overall, there were fewer living donor liver transplants than in 2019 [27, 29]. However, changes in transplant rates throughout 2020 were likely also impacted by the changes in liver allocation that went into effect immediately prior to the onset of the pandemic. 


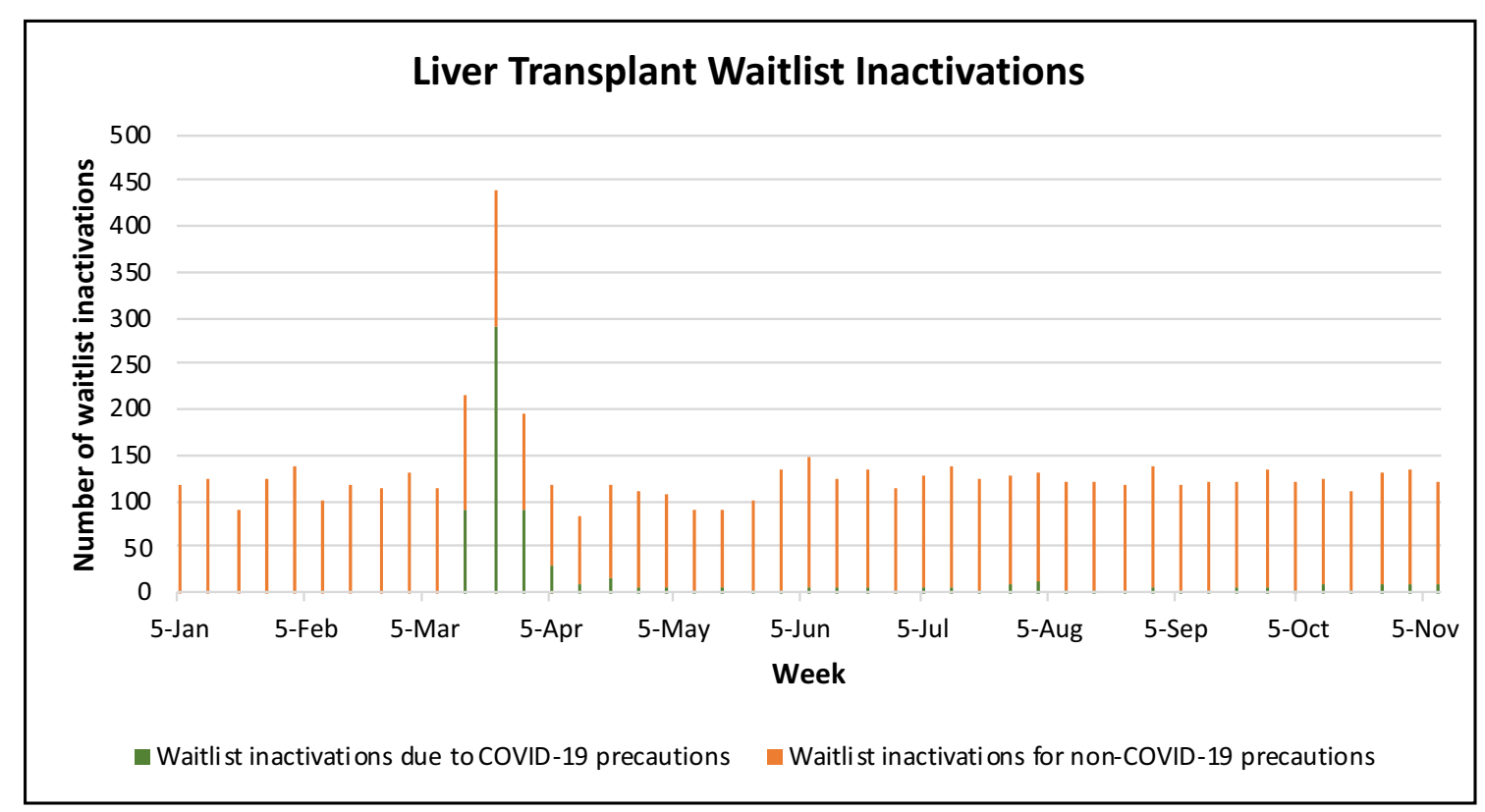

Fig. 2. Liver transplant waitlist inactivations in the US in 2020

\section{SARS-CoV-2 testing prior to liver transplantation}

Society guidelines recommend testing for SARS-CoV-2 for both liver transplant donors and recipients $[9 \bullet, 10 \bullet, 30]$. All transplant recipients undergo nasopharyngeal PCR testing prior to surgery, and all Organ Procurement Organizations (OPOs) now use RNA testing from nasopharyngeal and/or bronchoalveolar lavage specimens for organ donors, ideally within $72 \mathrm{~h}$ of organ recovery. Because there is a substantial rate of false-negative SARS-CoV-2 testing, imaging with chest X-ray or chest CT should be considered in potential recipients or donors who have negative RNA testing but concerning symptoms, in order to more definitively exclude active COVID-19. Recommended practice for recipient and donor SARS-CoV-2 testing according to the American Society of Transplantation (AST) is shown in Fig. 3.

\section{SARS-CoV-2 positivity in liver transplant recipients}

Ideally, all liver transplant donors and recipients would test negative for SARSCoV-2 at the time of transplantation, and outside of rare circumstances, transplantation is not routinely recommended for patients with active COVID-19. In patients who have recovered from COVID-19, it is unknown whether SARSCoV-2 may reactivate to cause illness-including hepatic injury-after transplant and initiation of immunosuppression. Furthermore, it is unknown whether risk and severity of long-term complications of COVID-19-such as kidney injury, fatigue, myopathy, and autonomic dysregulation-may be increased in patients receiving immunosuppression [31, 32]. As such, society guidelines currently recommend that transplant take place at least 14-21 days

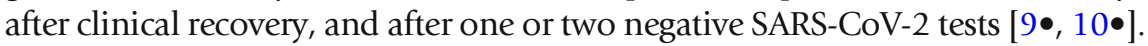
Multiple case reports documented successful liver transplant after the recipient has recovered from COVID-19, with most occurring at least 30 days after last 


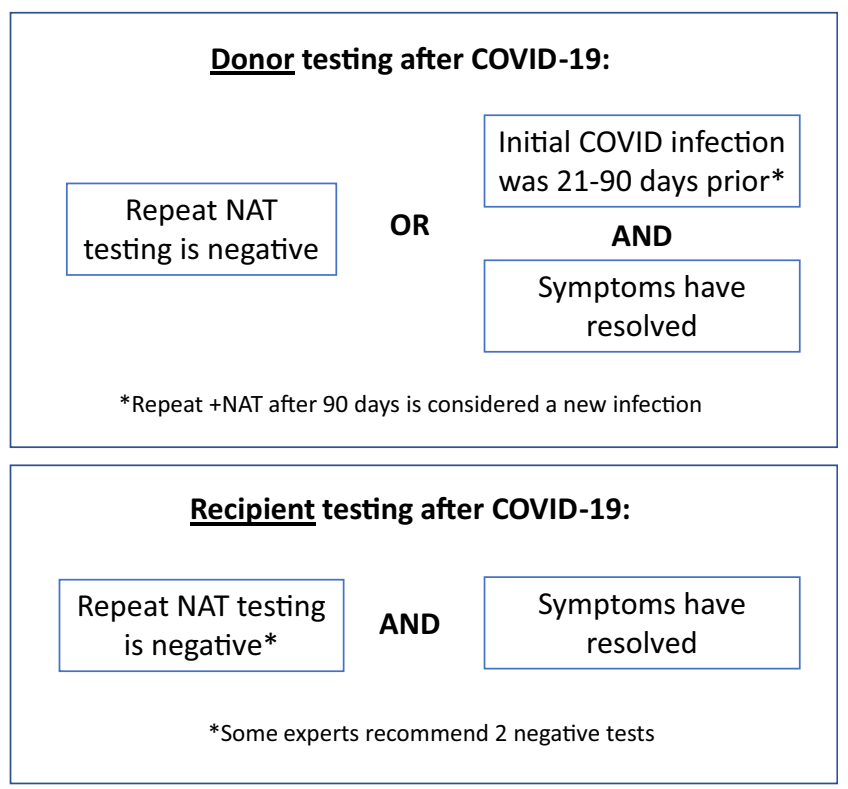

Fig. 3. Donor and recipient testing after COVID-19

positive test [33-35]. More recently, multiple centers have reported transplantation as early as two weeks after positive SARS-CoV-2 test, without subsequent complications related to COVID-19 [36, 37].

For patients with chronic liver disease, there may be prolonged SARS-CoV-2 viral shedding for weeks or even months after clinical recovery from the acute illness $[38,39]$. As such, it may be impractical or unduly restrictive to require negative SARS-CoV-2 testing for patients with high risk of morbidity and mortality while awaiting transplant, such as patients with high Model for End-stage Liver Disease (MELD) score or those with acute liver failure. Initial reports of liver transplantation in SARS-CoV-2 positive patients, while rare, suggest that transplant in this context may be safe: in a case of a SARS-CoV-2positive patient with Hepatitis B-/Hepatitis D-associated chronic liver disease, liver transplantation from a SARS-CoV-2-positive donor was successful, with good graft function and no evidence of viral hepatitis by two months posttransplant [40]. In patients who are recovered from active COVID-19, therefore, liver transplantation may still be considered, even in the presence of prolonged viral shedding.

An even more challenging situation is that in which patients meet indications for urgent or emergent liver transplantation while acutely ill from COVID19. This may arise in the context of acute-on-chronic liver failure and/or acute liver failure among patients who have symptomatic COVID-19 but cannot wait the weeks required to clear the infection. While this complication is rare, liver transplantation may be the only potential life-saving intervention for those patients. To our knowledge, there is only one case currently published of a liver transplant in this context, in which a patient with active COVID-19 with respiratory impairment developed acute liver failure-thought to be from acute Wilsonian crisis, possibly precipitated by COVID-19 infection-successfully underwent liver transplantation [41]. This patient ultimately converted to have 
negative RNA testing on day 27 posttransplant, after treatment with remdesivir, and had excellent graft function at time of hospital discharge. This case importantly demonstrates that liver transplantation for patients with acute liver failure may be a viable therapeutic option, but the safety of this approach is unknown. Important considerations may include the extent of lung injury that is present at the time of transplant, as respiratory failure remains the main cause of death even among patients with advanced liver disease.

SARS-CoV-2 positivity in liver transplant donors and considerations around hepatic infection

Organ recovery from donors with history of resolved COVID-19 who now have negative SARS-CoV-2 RNA testing is considered safe, and this practice has been widely adopted $[9 \bullet, 10 \bullet \bullet, 42]$. The risk of SARS-CoV-2 transmission from a liver donor to a recipient is also considered low if the donor has resolved COVID-19 with persistent positive RNA testing 21-90 days after disease onset, and use of these organs is often appropriate. In donors with a history of mild COVID-19 with disease onset more than 10 but fewer than 21 days prior, the risk of SARS$\mathrm{CoV}-2$ transmission is unknown. More than 90 days after disease onset, SARSCoV-2 positivity could reflect reinfection, and the risk of viral transmission is similarly unknown.

The risk associated with liver donation from SARS-CoV-2-positive donors depends in some ways upon whether SARS-CoV-2 directly infects the liver, a question that remains controversial. Because hepatic cholangiocytes, endothelial cells, and hepatocytes express angiotensin-converting enzyme-2 (ACE-2), the proposed host cell receptor of SARS-CoV-2, and because abnormal liver function tests are common in patients with COVID-19, there is concern that SARS-CoV-2 could directly infect hepatic tissue [43]. Analysis of postmortem liver histology in a series of patients who had COVID-19 revealed weak-positive staining of cholangiocytes and of histiocytes within portal tracts in a minority of cases, but not of portal endothelial cells or hepatocytes [44]. In another postmortem series of liver histology in patients with COVID-19, viral RNA by PCR was detectable in half of patients [19]. One case series including two postmortem liver biopsies showed coronavirus particles in hepatocyte cytoplasm, with evidence of typical viral infectious lesions [45]. Other histologic findings were nonspecific, such as hepatic steatosis and acute hepatitis. In a series of three patients with prolonged cholestasis following critical COVID-19 illness, liver histology demonstrated severe cholangiocyte injury and intrahepatic microangiopathy, likely reflecting ischemic injury [23]. In all, these findings suggest that SARS-CoV-2 RNA is present in some patients with COVID-19. However, whether there is active viral replication in the liver-for example, in cholangiocytes-is unknown. Therefore, even if a transplant donor liver were to contain SARS-CoV-2 RNA, it is unknown whether this could lead to infection in the recipient. To date, the only described case of solid organ donor-torecipient transmission of SARS-CoV-2 was in a lung transplant [46].

\section{Clinical outcomes of COVID-19 in liver transplant recipients}

Liver transplant recipients have theoretical increased risk for severe infectionrelated illness compared to the general population, especially due to use of immunosuppressive medications. A number of studies have evaluated clinical 
outcomes of COVID-19 in liver and other solid organ transplant recipients (summarized in Table 1). Several multicenter studies in the U.S. and in Europe have described a mortality rate near or above $20 \%$ among liver transplant recipients with COVID- $19[4 \bullet, 47,48,49 \bullet \bullet, 50,51]$. In studies comparing liver transplant recipients to matched nonliver transplant comparator groups, however, mortality did not differ significantly, though liver transplant recipients did

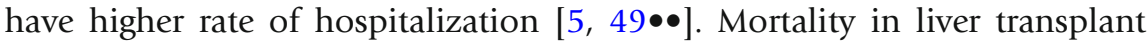
recipients with COVID-19 has been associated with usual patient risk factors for severe disease, including increased age-especially age over 60 years-and medical comorbidities including renal dysfunction and nonliver cancer $[\bullet 4,48$, $50,52]$.

COVID-19 infection often leads to changes to immunosuppressive regimens in liver transplant recipients. In a multicenter study from Europe including 57 liver transplant recipients, for example, immunosuppression was reduced in $37 \%$ of patients and discontinued in $7 \%$ of patients [53]. In the U.S. multicenter COVID-19 in chronic liver disease (COLD) consortium, immunosuppression was modified in $49 \%$ of liver transplant recipients with COVID-19 [50]. In both studies, reduction of immunosuppression in this setting was not associated with acute liver injury or other clinical outcomes. Studies suggest that mycophenolate use may be associated with severe disease, potentially due to T-cell depletion synergistically with SARS-CoV-2 [4•, 54]. On the other hand, calcineurin inhibitors and everolimus have not been associated with more severe illness from COVID-19; in fact, in one study, tacrolimus use was associated with reduced mortality [51]. In all, in liver transplant recipients with COVID-19, management of immunosuppression must be individualized for each patient. In patients with severe disease or high risk for disease progression, reduction of immunosuppression can be considered, and in this case, providers should consider preferentially reducing the dose of mycophenolate over other medications. In patients receiving calcineurin inhibitors, serum medication levels should be closely monitored, as SARS-CoV-2 infection may increase serum tacrolimus concentration in solid organ transplant recipients [55].

\section{Management of COVID-19 in liver transplant candidates and recipients}

Multiple treatments have been evaluated for management of COVID-19, especially for patients with severe (SpO2 $<94 \%$ on room air) or critical (ICU, mechanical ventilation, septic shock, or extra-corporeal membrane oxygenation [ECMO]) disease. Current recommendations from the Infectious Diseases Society of America (IDSA) updated in March 2021 suggest use of corticosteroids, tocilizumab (an interleukin [IL]-6 inhibitor), and/or remdesivir (an antiviral) in patients who are hospitalized with severe or critical disease [6]. There are no prospective clinical trials specifically evaluating these therapies in patients with chronic liver disease or in liver transplant recipients, and these patients are often managed similarly to other patients based on severity of acute illness. However, these therapies may entail significant hepatotoxicity that must be considered when selecting and monitoring response to therapy. 
Drug-induced liver injury (DILI) characterized by elevations in serum aminotransferases may occur in $10-50 \%$ of patients receiving remdesivir, and has been noted as the most common drug-related adverse effect [5660]. Hepatotoxicity increases with longer duration of drug use. Use of remdesivir is not currently recommended in patients with aminotransferase levels $>5$ times the upper limit of normal, and cessation of use is recommend in patients who develop alanine aminotransferase (ALT) level $>10$ times the upper limit of normal [61]. Tocilizumab has also been associated with elevated aminotransferases, including severe elevations [62-64]. While a large proportion of patients receiving tocilizumab may already have elevated aminotransferases prior to medication initiation, use of tocilizumab is associated with development of de novo liver function test abnormalities [65].

Additional combination therapies also suggested by the IDSA are bamlanivimab-etesevimab in ambulatory patients with mild-moderate disease or patients hospitalized for other reasons who have high risk of progression to severe disease, and baricitinib-remdesivir for hospitalized patients with severe disease who cannot receive corticosteroids [6]. Baricitinib, a janus kinase (JAK) inhibitor that may block the effects of IL-6, has shown efficacy when used in combination with remdesivir in patients with severe or critical COVID-19 [66]. In November 2020, the U.S. Food and Drug Administration (FDA) issued an Emergency Use Authorization (EUA) for use of baricitinib-remdesivir in hospitalized adult and pediatric patients requiring supplemental oxygen, invasive mechanical ventilation, or ECMO in whom steroids cannot be used [67]. Baricitinib may be associated with hepatocellular DILI, and when this occurs then treatment interruption is recommended.

Multiple monoclonal antibodies targeting SARS-CoV-2 virus have been developed for treatment of COVID-19. The combination of bamlanivimab and etesevimab, two neutralizing monoclonal antibodies that bind epitopes in the spike protein of SARS-CoV-2, has shown efficacy in reducing viral load and preventing hospitalization in outpatients with mild-moderate disease [68]. In February 2021, the FDA issued an EUA for bamlanivimab-etesevimab combination therapy among ambulatory patients with mild-moderate COVID-19 with high risk of disease progression [69]. The specific eligible patients include those with an immunocompromising condition and those receiving immunosuppressive treatment [70]. This therapy is clearly indicated in liver transplant recipients, and we recommend its use for eligible patients. Where available and accessible, monoclonal antibody therapy may also be of benefit to patients with chronic liver disease.

It is important to exercise caution and to closely monitor liver function in patients with chronic liver disease and liver transplant recipients receiving targeted therapies for COVID-19. Considering the immense morbidity and mortality associated with COVID-19, however, use of these therapies is often appropriate even in light of the risk of hepatotoxicity. In studies in which liver transplant recipients have received targeted therapies for COVID-19, no significant adverse effects of medication have been noted. Among solid organ transplant recipients, the most data available is for remdesivir, with findings supporting its use in these patients $[47,49 \bullet, 71,72 \bullet, 73]$. 


\section{COVID-19 vaccination in the context of liver transplantation}

\section{Conclusions}

Vaccines against COVID-19 have recently become available, and are increasingly accessible nationwide. While no studies have been conducted specifically in patients with chronic liver disease or after liver transplantation, vaccination is recommended $[7,8 \bullet]$. For liver transplant candidates, society guidelines recommend vaccination in patients and their household contacts, to be completed at least two weeks prior to transplantation. Liver transplant recipients should also complete vaccination, which can be administered at least three months after transplantation in patients receiving B or T cell ablative therapies. Solid organ transplant recipients receiving immunosuppression may have less robust immune response to vaccination, as to natural COVID-19 infection, than other patients; as such, vaccine administration prior to transplant is preferred when possible $[74,75,76,77 \bullet, 78]$.

COVID-19 has significantly impacted liver transplant candidates and recipients and the practice of liver transplantation. While morbidity and mortality from COVID-19 in patients with liver disease is substantial and may exceed that of the general population, advances in therapy and increased access to vaccination provide promising management strategies for these patients. SARS-CoV-2 testing of potential liver transplant donors and recipients has aimed to avoid transplantation involving patients with active COVID-19. There remains a dire need for improved understanding of the true risk of hepatic and systemic viral reactivation after transplantation involving SARS-CoV-2 positive donors or recipients. While controversial, there may be opportunity for safe and effective liver transplant even in patients with active COVID-19, including those with SARS-CoV-2-associated fulminant liver failure. Further studies of intrahepatic SARS-CoV-2 replication and of posttransplant outcomes using SARS-CoV-2positive donors and recipients are needed.

\section{References}

Papers of particular interest, published recently, have been highlighted as:

- Of importance

-• Of major importance

1. Gardner L, Dong E. Coronavirus COVID-19 global cases by the Center for Systems Science and Engineering (CSSE) at Johns Hopkins University (JHU). 2020 [updated April 11, 2021. Available from: https:// coronavirus.jhu.edu/map.html.

2•. Singh S, Khan A. Clinical characteristics and outcomes of coronavirus disease 2019 among patients with preexisting liver disease in the United States: a multicenter research network study. Gastroenterology. 2020;159(2):768-71 e3. The first study to describe outcomes of COVID-19 in patients with chronic liver disease and cirrhosis.

3. Oyelade T, Alqahtani J, Canciani G. Prognosis of COVID-19 in patients with liver and kidney diseases: 
an early systematic review and meta-analysis. Trop Med Infect Dis. 2020;5(2).

4•. Colmenero J, Rodriguez-Peralvarez M, Salcedo M, Arias-Milla A, Munoz-Serrano A, Graus J, et al. Epidemiological pattern, incidence, and outcomes of COVID-19 in liver transplant patients. J Hepatol. 2021;74(1):148-55. The first study to provide a detailed description of immunosuppression changes in liver transplant recipients and impact on outcomes.

5. Mansoor E, Perez A, Abou-Saleh M, Sclair SN, Cohen S, Cooper GS, et al. Clinical characteristics, hospitalization, and mortality rates of coronavirus disease 2019 among liver transplant patients in the United States: a multicenter research network study. Gastroenterology. 2021;160(1):459-6.

e1.

6. Bhimraj A, Morgan RL, Shumaker AH, Lavergne V, Baden L, Cheng VC, et al. Infectious Diseases Society of America guidelines on the treatment and management of patients with COVID-19. Infectious Diseases Society of America. 2021;Version 4.1.1.

7. Fix OK, Blumberg EA, Chang KM, Chu J, Chung RT, Goacher EK, et al. AASLD expert panel consensus statement: vaccines to prevent COVID-19 infection in patients with liver disease. Hepatology. 2021.

8•. COVID-19 vaccine FAQ sheet: American Society of Transplantation (AST); 2021 [updated March 18, 2021. Available from: https://www.myast.org/sites/ default/files/2021\%2003\%2018\%20COVID19\% 20VACCINE\%20FAQS_update.pdf. A major society concencus guideline regarding management of COVID-19 in liver transplant candidates and recipients.

9•. Clinical best practice advice for hepatology and liver transplant providers during the COVID-19 pandemic: AASLD expert panel consensus statement. Alexandria, Virginia: American Association for the Study of Liver Diseases (AASLD); [updated March 9, 2021. Available from: https://www.aasld.org/sites/default/files/202103/AASLD-COVID19-

ExpertPanelConsensusStatement-March92021.pdf. A major society concencus guideline regarding management of COVID-19 in liver transplant candidates and recipients.

10. Summary of current evidence and informationdonor SARS-CoV-2 testing \& organ recovery from donors with a history of COVID-19 Organ Procurement and Transplant Network (OPTN); 2021 [updated February 17, 2021. Available from: https:// optn.transplant.hrsa.gov/media/4424/sars-cov-2summary-of-evidence.pdf. Guidance from the organ procurement and transplantation network (OPTN) regarding SARS-CoV-2 testing in organ donors and recipients.

11. Iavarone $\mathrm{M}, \mathrm{D}^{\prime}$ Ambrosio R, Soria A, Triolo $\mathrm{M}$, Pugliese N, Del Poggio P, et al. High rates of 30-day mortality in patients with cirrhosis and COVID-19. J Hepatol. 2020;73(5):1063-71.
12•• $\quad$ Kim D, Adeniji N, Latt N, Kumar S, Bloom PP, Aby ES, et al. Predictors of outcomes of COVID-19 in patients with chronic liver disease: US Multi-center Study. Clin Gastroenterol Hepatol. 2020. The largest US cohort describing patients with chronic liver disease and cirrhosis with COVID-19.

13••. Marjot T, Moon AM, Cook JA, Abd-Elsalam S, Aloman C, Armstrong MJ, et al. Outcomes following SARS-CoV-2 infection in patients with chronic liver disease: An international registry study. J Hepatol. 2021;74(3):567-77. The first international study evaluating outcomes of COVID-19 in patients with chronic liver disease and cirrhosis, including a large comparator group.

14. Sarin SK, Choudhury A, Lau GK, Zheng MH, Ji D, AbdElsalam S, et al. Pre-existing liver disease is associated with poor outcome in patients with SARS CoV2 infection; The APCOLIS Study (APASL COVID-19 Liver Injury Spectrum Study). Hepatol Int. 2020;14(5):690700.

15. Bajaj JS, Garcia-Tsao G, Biggins SW, Kamath PS, Wong $\mathrm{F}, \mathrm{McGeorge}$, et al. Comparison of mortality risk in patients with cirrhosis and COVID-19 compared with patients with cirrhosis alone and COVID-19 alone: multicentre matched cohort. Gut. 2021;70(3):531-6.

16. Hashemi N, Viveiros K, Redd WD, Zhou JC, McCarty TR, Bazarbashi AN, et al. Impact of chronic liver disease on outcomes of hospitalized patients with COVID-19: a multicentre United States experience. Liver Int. 2020;40(10):2515-21.

17. Qi X, Liu Y, Wang J, Fallowfield JA, Wang J, Li X, et al. Clinical course and risk factors for mortality of COVID19 patients with pre-existing cirrhosis: a multicentre cohort study. Gut. 2021;70(2):433-6.

18. Fan Z, Chen L, Li J, Cheng X, Yang J, Tian C, et al. Clinical features of COVID-19-related liver functional abnormality. Clin Gastroenterol Hepatol. 2020;18(7):1561-6.

19. Lagana SM, Kudose S, Iuga AC, Lee MJ, Fazlollahi L, Remotti HE, et al. Hepatic pathology in patients dying of COVID-19: a series of 40 cases including clinical, histologic, and virologic data. Mod Pathol. 2020;33(11):2147-55.

20. Phipps MM, Barraza LH, LaSota ED, Sobieszczyk ME, Pereira MR, Zheng EX, et al. Acute liver injury in COVID-19: prevalence and association with clinical outcomes in a large US cohort. Hepatology. 2020;72:807-17.

21. Richardson S, Hirsch JS, Narasimhan M, Crawford JM, McGinn T, Davidson KW, et al. Presenting characteristics, comorbidities, and outcomes among 5700 patients hospitalized with COVID-19 in the New York City area. JAMA. 2020;323(20):2052-9.

22. Goyal P, Choi JJ, Pinheiro LC, Schenck EJ, Chen R, Jabri A, et al. Clinical characteristics of Covid-19 in New York City. N Engl J Med. 2020;382(24):2372-4.

23. Roth NC, Kim A, Vitkovski T, Xia J, Ramirez G, Bernstein D, et al. Post-COVID-19 cholangiopathy: a novel entity. Am J Gastroenterol. 2021;116:1077-82. 
24. Melquist S, Estepp K, Aleksandrovich Y, Lee A, Beiseker A, Hamedani FS, et al. COVID-19 presenting as fulminant hepatic failure: a case report. Medicine (Baltimore). 2020;99(43):e22818.

25. Haji Esmaeil Memar E, Mamishi S, Sharifzadeh Ekbatani M, Alimadadi H, Yaghmaei B, Chegini V, et al. Fulminant hepatic failure: a rare and devastating manifestation of Coronavirus disease 2019 in an 11-yearold boy. Arch Pediatr. 2020;27(8):502-5.

26. Efe C, Dhanasekaran R, Lammert C, Ebi B, Higuera-de la Tijera F, Aloman C, et al. Outcome of COVID-19 in patients with autoimmune hepatitis: an international multi-centre study. Hepatology. 2021.

27. Strauss AT, Boyarsky BJ, Garonzik-Wang JM, Werbel W, Durand CM, Avery RK, et al. Liver transplantation in the United States during the COVID-19 pandemic: national and center-level responses. Am J Transplant. 2020.

28. Strauss AT, Cartier D, Gunning BA, Boyarsky BJ, Snyder J, Segev DL, et al. Impact of the COVID-19 pandemic on commercial airlines in the United States and implications for the kidney transplant community. Am J Transplant. 2020;20(11):3123-30.

29. Annual record trend continues for deceased organ donation, deceased donor transplants.: Department of Health and Human Services Organ Procurement and Transplantation Network; 2020 [Available from: https://optn.transplant.hrsa.gov/news/annual-recordtrend-continues-for-deceased-organ-donationdeceased-donor-transplants/.

30. Galvan NTN, Moreno NF, Garza JE, Bourgeois S, Hemmersbach-Miller M, Murthy B, et al. Donor and transplant candidate selection for solid organ transplantation during the COVID-19 pandemic. Am J Transplant. 2020;20(11):3113-22.

31. Manzano GS, Woods JK, Amato AA. Covid-19associated myopathy caused by type I interferonopathy. N Engl J Med. 2020;383(24):2389_ 90.

32. Brodin P. Immune determinants of COVID-19 disease presentation and severity. Nat Med. 2021;27(1):2833.

33. Tabrizian P, Pourmand K, Florman S. Liver Transplantation in a patient with human immunodeficiency virus and coronavirus disease 2019. Liver Transpl. 2020.

34. Niess H, Borner N, Muenchhoff M, Khatamzas E, Stangl M, Graf A, et al. Liver transplantation in a patient after COVID-19-rapid loss of antibodies and prolonged viral RNA shedding. Am J Transplant. 2021;21(4):1629-32.

35. Dhand A, Bodin R, Wolf DC, Schluger A, Nabors C, Nog R, et al. Successful liver transplantation in a patient recovered from COVID-19. Transpl Infect Dis. 2020:e13492.

36. Kulkarni AV, Parthasarathy K, Kumar P, Sharma M, Reddy R, Chaitanya Akkaraju Venkata K, et al. Early liver transplantation after COVID-19 infection: the first report. Am J Transplant. 2021.
37. Malleeswaran S, Mohanka R, Yalakanti RB, Patcha R, Rao PS, Appusamy E, et al. Living donor hepatectomy after proven SARS-CoV-2 infection: first report of 9 cases from 3 centers. Transplantation. 2021;Publish Ahead of Print.

38. Kushner T, Cafardi J. Chronic liver disease and COVID19: alcohol use disorder/alcohol-associated liver disease, nonalcoholic fatty liver disease/nonalcoholic steatohepatitis, autoimmune liver disease, and compensated cirrhosis. Clin Liver Dis (Hoboken). 2020;15(5):195-9.

39. Ji D, Qin E, Xu J, Zhang D, Cheng G, Wang Y, et al. Non-alcoholic fatty liver diseases in patients with COVID-19: a retrospective study. J Hepatol. 2020;73(2):451-3.

40. Manzia TM, Gazia C, Lenci I, Angelico R, Toti L, Monaco A, et al. Liver transplantation performed in a SARS-CoV-2 positive hospitalized recipient using a SARS-CoV-2 infected donor. Am J Transplant. 2021.

41. Yohanathan L, Corsini Campioli C, Mousa OY, Watt K, Friedman DZP, Shah V, et al. Liver transplantation for acute liver failure in a SARS-CoV-2PCR-positive patient. Am J Transplant. 2021.

42. Neidlinger NA, Smith JA, D'Alessandro AM, Roe D, Taber TE, Pereira MR, et al. Organ recovery from deceased donors with prior COVID-19: a case series. Transpl Infect Dis. 2020:e13503.

43. Schaefer EAK, Arvind A, Bloom PP, Chung RT. Interrelationship between coronavirus infection and liver disease. Clin Liver Dis (Hoboken). 2020;15(5):17580 .

44. Zhao CL, Rapkiewicz A, Maghsoodi-Deerwester M, Gupta M, Cao W, Palaia T, et al. Pathological findings in the postmortem liver of patients with coronavirus disease 2019 (COVID-19). Hum Pathol. 2021;109:5968.

45. Wang Y, Liu S, Liu H, Li W, Lin F, Jiang L, et al. SARSCoV-2 infection of the liver directly contributes to hepatic impairment in patients with COVID-19. J Hepatol. 2020;73(4):807-16.

46. Kaul DR, Valesano AL, Petrie JG, Sagana R, Lyu D, Lin J, et al. Donor to recipient transmission of SARS-CoV-2 by lung transplantation despite negative donor upper respiratory tract testing. Am J Transplant. 2021.

47. Pereira MR, Mohan S, Cohen DJ, Husain SA, Dube GK, Ratner LE, et al. COVID-19 in solid organ transplant recipients: Initial report from the US epicenter. Am J Transplant. 2020;20(7):1800-8.

48. Belli LS, Duvoux C, Karam V, Adam R, Cuervas-Mons $\mathrm{V}$, Pasulo L, et al. COVID-19 in liver transplant recipients: preliminary data from the ELITA/ELTR registry. Lancet Gastroenterol Hepatol. 2020;5(8):724-5.

49••. Webb GJ, Marjot T, Cook JA, Aloman C, Armstrong MJ, Brenner EJ, et al. Outcomes following SARSCoV-2 infection in liver transplant recipients: an international registry study. Lancet Gastroenterol Hepatol. 2020;5(11):1008-16. The largest study to date of COVID-19 in liver transplant recipients, including patients from 18 countries. 
50. Rabiee A, Sadowski B, Adeniji N, Perumalswami PV, Nguyen V, Moghe A, et al. Liver injury in liver transplant recipients with coronavirus disease 2019 (COVID-19): U.S. multicenter experience. Hepatology. 2020;72(6):1900-11.

51. Belli LS, Fondevila C, Cortesi PA, Conti S, Karam V, Adam R, et al. Protective role of tacrolimus, deleterious role of age and comorbidities in liver transplant recipients with Covid-19: results from the ELITA/ELTR Multi-center European Study. Gastroenterology. 2021;160(4):1151-6.

e3.

52. Softeland JM, Friman G, von Zur-Muhlen B, Ericzon BG, Wallquist C, Karason K, et al. COVID-19 in solid organ transplant recipients: a national cohort study from Sweden. Am J Transplant. 2021.

53. Becchetti C, Zambelli MF, Pasulo L, Donato MF, Invernizzi F, Detry O, et al. COVID-19 in an international European liver transplant recipient cohort. Gut. 2020;69(10):1832-40.

54. Wang F, Nie J, Wang H, Zhao Q, Xiong Y, Deng L, et al. Characteristics of peripheral lymphocyte subset alteration in COVID-19 pneumonia. J Infect Dis. 2020;221(11):1762-9.

55. Salerno DM, Kovac D, Corbo H, Jennings DL, Lee J, Choe J, et al. SARS-CoV-2 infection increases tacrolimus concentrations in solid-organ transplant recipients. Clin Transplant. 2021;35(3):e14193.

56. Goldman JD, Lye DCB, Hui DS, Marks KM, Bruno R, Montejano R, et al. Remdesivir for 5 or 10 days in patients with severe Covid-19. N Engl J Med. 2020;383(19):1827-37.

57. Wang Y, Zhang D, Du G, Du R, Zhao J, Jin Y, et al. Remdesivir in adults with severe COVID-19: a randomised, double-blind, placebo-controlled, multicentre trial. Lancet. 2020;395(10236):1569-78.

58. Beigel JH, Tomashek KM, Dodd LE, Mehta AK, Zingman BS, Kalil AC, et al. Remdesivir for the treatment of Covid-19-final report. N Engl J Med. 2020;383(19):1813-26.

59. Montastruc F, Thuriot S, Durrieu G. Hepatic disorders with the use of remdesivir for coronavirus 2019. Clin Gastroenterol Hepatol. 2020;18(12):2835-6.

60. Antinori S, Cossu MV, Ridolfo AL, Rech R, Bonazzetti C, Pagani G, et al. Compassionate remdesivir treatment of severe Covid-19 pneumonia in intensive care unit (ICU) and Non-ICU patients: clinical outcome and differences in post-treatment hospitalisation status. Pharmacol Res. 2020;158:104899.

61. Center for Drugs Evaluation and Research Application Number: 214787Orig1s000 Summary Review: Food and Drug Administration; 2020 [Available from: https://www.accessdata.fda.gov/drugsatfda_docs/nda/ 2020/214787Orig1s000Sumr.pdf.

62. Stone JH, Frigault MJ, Serling-Boyd NJ, Fernandes AD, Harvey L, Foulkes AS, et al. Efficacy of tocilizumab in patients hospitalized with Covid-19. N Engl J Med. 2020;383(24):2333-44.
63. Salvarani C, Dolci G, Massari M, Merlo DF, Cavuto S, Savoldi L, et al. Effect of tocilizumab vs standard care on clinical worsening in patients hospitalized with COVID-19 pneumonia: a randomized clinical trial. JAMA Intern Med. 2021;181(1):24-31.

64. Gupta S, Wang W, Hayek SS, Chan L, Mathews KS, Melamed ML, et al. Association between early treatment with tocilizumab and mortality among critically ill patients with COVID-19. JAMA Intern Med. 2021;181(1):41-51.

65. Piano S, Dalbeni A, Vettore E, Benfaremo D, Mattioli $\mathrm{M}$, Gambino CG, et al. Abnormal liver function tests predict transfer to intensive care unit and death in COVID-19. Liver Int. 2020;40(10):2394-406.

66. Kalil AC, Patterson TF, Mehta AK, Tomashek KM, Wolfe CR, Ghazaryan V, et al. Baricitinib plus remdesivir for hospitalized adults with Covid-19. N Engl J Med. 2021;384(9):795-807.

67. Fact Sheet for Healthcare Providers Emergency Use Authorization (EUA) of baricitinib.: Food and Drug Administration; 2021 [Available from: https://www. fda.gov/media/143823/download.

68. Gottlieb RL, Nirula A, Chen P, Boscia J, Heller B, Morris $\mathrm{J}$, et al. Effect of bamlanivimab as monotherapy or in combination with etesevimab on viral load in patients with mild to moderate COVID-19: a randomized clinical trial. JAMA. 2021;325(7):632-44.

69. Frequently asked questions on the Emergency Use Authorization for bamlanivimab and etesevimab.: Food and Drug Administration; 2021 [Available from: https://www.fda.gov/media/145808/download.

70. The COVID-19 treatment guidelines panel's statement on the emergency use authorization of the bamlanivimab plus etesevimab combination for the treatment of COVID-19: National Institutes of Health; 2021 [Available from: https://www. covid19treatmentguidelines.nih.gov/statement-onbamlanivimab-plus-etesevimab-eua/.

71. Laracy JC, Verna EC, Pereira MR. Antivirals for COVID19 in solid organ transplant recipients. Curr Transplant Rep. 2020:1-11.

72• Pereira MR, Aversa MM, Farr MA, Miko BA, Aaron JG, Mohan S, et al. Tocilizumab for severe COVID-19 in solid organ transplant recipients: a matched cohort study. Am J Transplant. 2020;20(11):3198-205. The first study describing COVID-19 outcomes among solid organ transplant recipients.

73. Kates OS, Haydel BM, Florman SS, Rana MM, Chaudhry ZS, Ramesh MS, et al. COVID-19 in solid organ transplant: a multi-center cohort study. Clin Infect Dis. 2020.

74. Sester M, Gartner BC, Girndt M, Sester U. Vaccination of the solid organ transplant recipient. Transplant Rev (Orlando). 2008;22(4):274-84.

75. Chow J, Golan Y. Vaccination of solid-organ transplantation candidates. Clin Infect Dis. 2009;49(10):1550-6.

76. Danziger-Isakov L, Kumar D, Practice AICo. Vaccination of solid organ transplant candidates and 
recipients: guidelines from the American society of transplantation infectious diseases community of practice. Clin Transplant. 2019;33(9):e13563.

77•. Boyarsky BJ, Werbel WA, Avery RK, Tobian AAR, Massie AB, Segev DL, et al. Immunogenicity of a single dose of SARS-CoV-2 messenger RNA vaccine in solid organ transplant recipients. JAMA. 2021. The first description of response to vaccination against COVID-19 in solid organ transplant recipients.

78. Burack D, Pereira MR, Tsapepas DS, Harren P, Farr MA, Arcasoy S, et al. Prevalence and predictors of SARS-
CoV-2 antibodies among solid organ transplant recipients with confirmed infection. Am J Transplant. 2021.

\section{Publisher's Note}

Springer Nature remains neutral with regard to jurisdictional claims in published maps and institutional affiliations. 